\title{
JUURNAL_RU
}

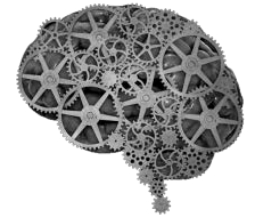

COMPANY GROUP "INTELLEKT"

Герасимов С.В., Мамбетова А.И., Шарыпова Е.А., Костин К.Б., Шумилин А.И., Шпиняк С.П., Пичхидзе С.Я. СГТУ им. Ю.А. Гагарина

Саратов, Россия

doi: 10.18411/lj2016-8-1-04

idsp 000001:lj2016-17-1-04

\section{Модернизация конструкции коленного эндопротеза}

Известно, что при тотальном эндопротезировании коленного сустава применяются различные материалы: металлы/полиэтилен/фторопласт. Непосредственно сами полимеры полиэтилен/ фторопласт используются в качестве вкладыша эндопротеза [1...2]. Ранее была установлена возможность улучшения механических и трибологических характеристик сверхвысокомолекулярного полиэтилена (СВМПЭ) путем введения частиц оксида алюминия Al2O3 определенной формы и дисперсности [3].

Цель работы: усовершенствование конструкции эндопротеза коленного сустава, увеличение срока его эксплуатации и получение эмпирических выводов о полезности предложенной технологии.

Предлагается нанесение на рабочую поверхность вкладыша коленного сустава оксида алюминия $\mathrm{Al} 2 \mathrm{O} 3$ методом магнетронного напыления.

Методика эксперимента. На образцы из фторопласта-4 (ПТФЭ) наносили Al2O3 с помощью магнетронно-распылительной системы на основе вакуумного универсального поста ВУП-4 в аргонокислородной плазме тлеющего разряда с пропорцией газов 1:1. Время осаждения пленки оксида алюминия составляло 20 мин., давление в камере порядка 2 Па. В качестве катода использовался высокочистый алюминий, толщина нанесенного покрытия Al2O3 составила 45 нм. Исследование морфологии поверхности и состава образцов проводили методом РЭМ/ЭДРА (растровой электронной микроскопии/энергодисперсионного рентгеновского анализа) на дифрактометре 
ARL X'TRA “Thermo Fisher Scientific” и микроскопе Aspex Explorer при ускоряющем напряжении электронного пучка $20 \mathrm{kV}$.

При нанесении Al2O3 происходит плотное укрывание поверхности ПТФЭ, рис.1в. По данным ЭДРА при модификации поверхности ПТФЭ возрастает концентрация $\mathrm{Al} 2 \mathrm{O} 3$, рис.1в. В процессе модельного износа вкладыша на машине трения МТ-2 в течение одного часа при 60 обор/мин. происходит образование каверн и разглаживание поверхности ПТФЭ, при уменьшении концентрации $\mathrm{Al} 2 \mathrm{O} 3$ в поверхностном слое, рис.1е...3. Износостойкость вкладыша повышается на $8 . .12 \%$. Близкая картина реального износа наблюдается для вкладыша СВМПЭ фирмы «Zimmer» после эндопротезирования.

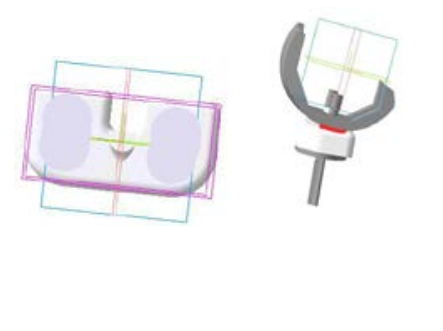

$a$

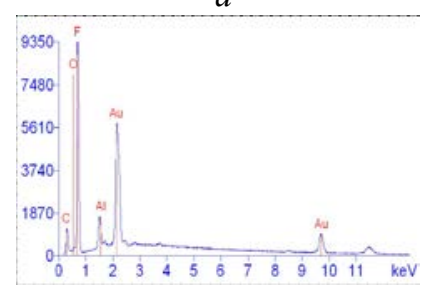

$\partial$

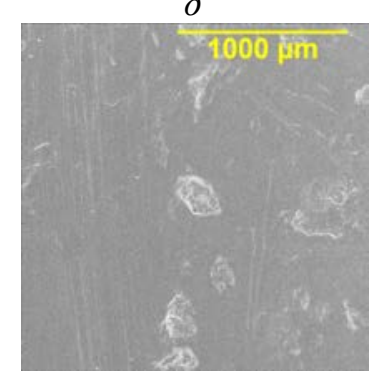

И

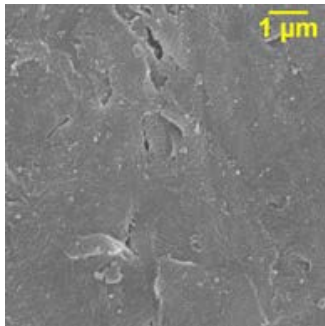

$\sigma$
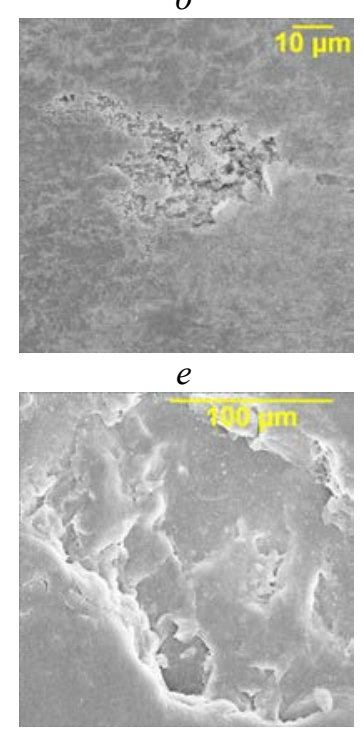

К

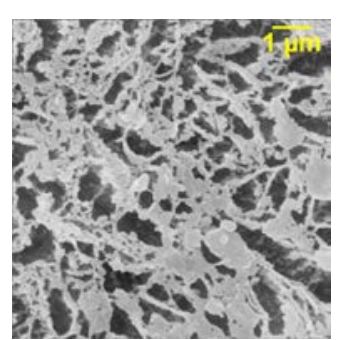

B

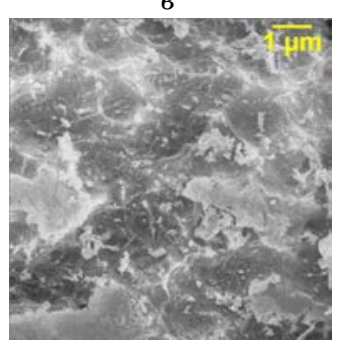

Ж

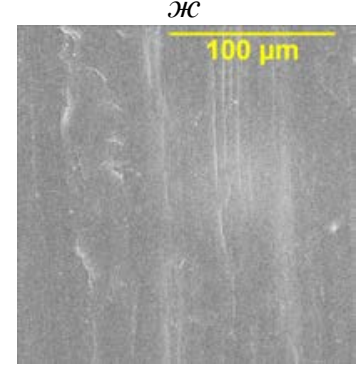

Л

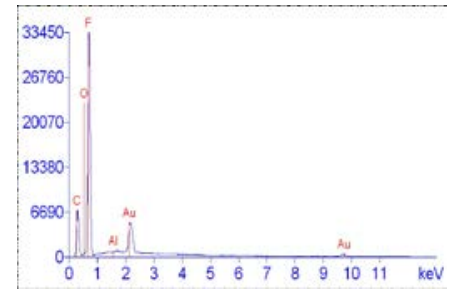

2

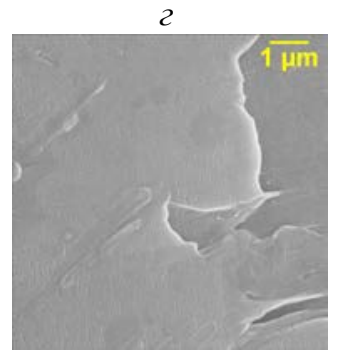

3

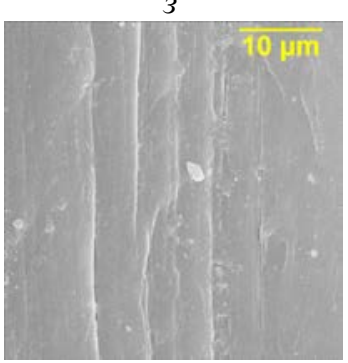

$\mathbf{M}$

Рис.1. Вкладыш ПТФЭ, где: а - области напыления Al2O3 , б-ПТФЭ до напыления, в - ПТФЭ после напыления Al2O3, г - ЭДРА ПТФЭ, - ЭДРА ПТФЭ + Al2O3, e - ПТФЭ + Al2O3 после износа, ж - каверна рис.1е, з - ПТФЭ рис.1е, к...м-вкладыи СВМПЭ после износа: каверны + дорожки

Выводы: показано, что в результате магнетронного напыления Al2O3 на поверхность фторопласта износостойкость повышается на $8 \ldots 12 \%$ при сохранении вязкой сердцевины. При этом нет ущерба пластичности вкладыша, позволяя ему переносить давление без образования трещин. 


\section{Литература:}

1. Эндопротезы крупных суставов: каталог / Джонсон \& Джонсон, 2012.-104 c.

2. Белякова О.В., Перинская И.В., Пичхидзе С.Я. Биосовместимое антимикробное покрытие эндопротеза коленного сустава. Самара: ЛЖурнал, 2016. - 2c.

3. Сенатов Ф.С. Микроструктура и свойства композитов медицинского назначения на основе СВМПЭ. Автореф. ...канд. техн. наук, М.: МИСиС, 2013. - 24c. 